\title{
The Caspian Littoral Strip in Azerbaijan is concerned with the State of Ecology of Heavily Exposed Metals
}

\author{
Rae ZH Aliyev* \\ Institute of Erosion and Irrigation NAS of Azerbaijan, Azerbaijan
}

Received: September 09, 2017; Published: September 22, 2017

*Corresponding author: Rae ZH Aliyev, Institute of Erosion and Irrigation NAS of Azerbaijan, Azerbaijan, Email: zakirakademik@mail.ru

\begin{abstract}
The presented article considers the natural-geographic location of Absheron, analyzes the presence of heavy metals such as zinc, mercury, arsen, copper in soils and plants remoteness from sources of pollution. Also, the presence of microorganisms was revealed, depending on the degree of soil contamination with heavy metals.
\end{abstract}

Keywords: Heavy metals; Microorganisms; Bacteria; Critical level

\section{Introduction}

Pollution of the environment has become one of the most important tasks of our time; a special role belongs to heavy metals, which have the ability to accumulate in soils and through them to enter food products, while contributing to soil degradation. Absheron Peninsula is an anthropogenic load; it is the most tense in Azerbaijan. The peninsula is located on the western shore of the Caspian Sea and is the southeastern tip of the Greater Caucasus Range, occupying a total area of 200 thousand hectares. In the middle part its width is $28 \mathrm{~km}$, and the length from east to west is $62 \mathrm{~km}$. Absolute marks of hypsometric level of the surface from 25 to $300-350 \mathrm{~m}$ above sea level. The relief is characterized by soft, smoothed and weakly dissected, representing a slightly wavy plain, with a progress toward the west, where it gradually elevates, which is explained, first of all, by the young age in geological terms of the relief and the insignificant height of the peninsula above the basis of erosion.

Aridity of the climate in the presence of sandy transformations and crowding of soil-forming rocks on the Absheron Peninsula contributed to the wide development of arid-denudation, solonchakdeflation and eolian relief forms. Peninsula corresponds Periclinal immersion southeast Grand continuation megaantiklinoriya Caucasian and folded complex sedimentary formations Mesozoic (Upper Cretaceous) paleogene, Quaternary systems, power to 8000-9000 m. The most widespread productive stratum deposits (average Pliocene), expressed sands lithological, sandstones, silts and clays and constitutes almost half of power (up to $3400 \mathrm{~m}$ ) the cut-Paleogenic neogene complex which assembled into a complex folds system [1].
The Absheron peninsula is characterized by a climate of moderately warm semi-deserts and dry steppes with dry summers. The greatest share of sunshine, about 30-35\% (1900-2500 hours per year) falls on summer. The total solar radiation throughout the territory varies from 120 to $135 \mathrm{kcal} / \mathrm{cm}^{2}$. The radiation balance is rather high $50-52 \mathrm{kcal} / \mathrm{cm}^{2}$. The average annual air temperature is $13.5-13.7^{\circ} \mathrm{C}$ in the northern and lower central parts, $14.2-14.6^{\circ}$ $\mathrm{C}$ in the extreme south of the peninsula [2]. The average annual precipitation is $130-150 \mathrm{~mm}$ per year. The greatest amount of precipitation up to $200 \mathrm{~mm}$ is observed in the Sumgait region. The soil cover of the Absheron peninsula was first investigated by VP Smirnov-Loginov [3]. Then Gasanov V.G. [4] composed of a largescale soil map Absheron peninsula (1: 50,000), where the grayhighlighted brown swamped primitive gray-brown, gray-brown incompletely, gray-brown saline soils and sands.

"We must clearly realize that the anthropogenic transformation of the biosphere in a sense has the nature of a global catastrophe and anthropogenic landscape - a landscape of the future. Apparently, in 100-200 years it will occupy the whole territory of the earth's surface with the possible exception of eternal ice and mountain peaks. The reasons for this lie in an uncontrolled and progressive growth of the Earth's population, non-stop building industry and agriculture, in the constant human need for energy sources other processes related "triumph of civilization" [5]. Measures to be taken by individuals, stakeholders and governments are important, complementary steps aimed at protecting the life support systems that not only ensure human well-being, but also the richness of the diversity of life on this planet [6]. 
The problems that arise in the design and operation of chemical enterprises have led to the fact that environmental problems have reached a critical level. The study of environmental problems occurring at the industrial site, the identification of the potential for environmental hazards in the industrial complex, is an urgent problem. Absheron was chosen as an array as a satellite to reduce the density of the industrial center of Baku. First, an industrial base of the petrochemical complex was created, on the basis of which other profiles also began to appear. The basis of the chemical industrial complex of Sumgait consists of such enterprises as "Orgsyntez", "Superphosphate", "CAM", and "Synthesis-rubber" (ethylene polyethylene), etc.

The highest toxicity values are found in heavy metals such as mercury, lead, cadmium, arsenic, vanadium, zinc, copper, cobalt, molybdenum and nickel. They enter the active biological cycle of substances. The soil has a certain capacity for exchange and absorption capacity. In turn, these properties depend on the content of organic matter, particle size distribution, and the reaction of the soil environment, which means that the soil and even their different horizons capable of absorbing and retaining in its composition various amounts of man-made emissions. [7] Contamination of soils by heavy metals is due to air when watering wastewater in formulating oil, exhaust gases, when making organic (rich cadmium), phosphorus (impurities have uranium and lead) fertilizers. When using pesticides (preparations with mercury) $[8,9]$.

Due to the fact that the soil is an object accumulating and supplying heavy metals to the biological chain, interest in studying its composition increases every year. At the same time, it is necessary to take into account that annually $350 \mathrm{~kg} /$ ha of harmful substances enter the soil with atmospheric emissions. It is noteworthy that in urban gardens, lead is concentrated in soil, zinc, copper is much larger than in arable soils. An increase in the concentration of heavy metals and aromatic hydrocarbons occurs in soils due to atmospheric precipitation from motorways [10]. Table 1 gives data on the content of heavy metals in the soil along the perimeter of industrial facilities (Table 1).

Table 1: Microelement composition of gray-brown soils of Sumgait massif (mg / kg).

\begin{tabular}{|c|c|c|c|c|c|c|c|c|}
\hline $\mathbf{N}$ & Depth.sm & $\mathrm{Cu}$ & Zn & $\mathbf{P b}$ & Cd & $\mathrm{Cr}$ & $\mathrm{Ni}$ & Co \\
\hline Clark & & 20 & 50 & 10 & $0,1-1$ & 20 & 40 & 8 \\
\hline \multirow[t]{2}{*}{1} & $0-15$ & 9,1 & 92 & 5 & 0,94 & 28 & 7 & 2,2 \\
\hline & $15-40$ & 12,0 & 94 & 5 & 0,88 & 29 & 9 & 1,4 \\
\hline \multirow[t]{2}{*}{2} & $0-26$ & 67,0 & 84 & 3 & 0.94 & 14 & 18 & 1,2 \\
\hline & $26-50$ & 38,0 & 66 & 8 & 0,82 & 19 & 34 & 4,2 \\
\hline \multirow[t]{2}{*}{3} & $0-16$ & 77,0 & 65 & 9 & 0,82 & 22 & 5 & 3,6 \\
\hline & $16-36$ & 26,0 & 72 & 5 & 0,84 & 20 & 8 & 3,7 \\
\hline \multirow[t]{2}{*}{4} & $0-16$ & 10,0 & 58 & 9 & 0,92 & 34 & 12 & 1,8 \\
\hline & $16-51$ & 9,0 & 62 & 5 & 0,62 & 38 & 19 & 2,8 \\
\hline \multirow[t]{2}{*}{5} & $0-20$ & 16,0 & 88 & 3 & 0,36 & 42 & 6 & 1,8 \\
\hline & $20-31$ & 9.0 & 62 & 4 & 0,37 & 68 & 7 & 2,6 \\
\hline \multirow[t]{2}{*}{6} & $0-22$ & 30 & 62 & 9 & 0,28 & 25 & 8 & 3,6 \\
\hline & $22-35$ & 22 & 65 & 12 & 0,51 & 28 & 5 & 3,4 \\
\hline \multirow[t]{2}{*}{7} & $0-15$ & 28 & 48 & 9 & 0,28 & 9 & 11 & 5,2 \\
\hline & $15-35$ & 9 & 62 & 21 & 0,57 & 38 & 7 & 1,8 \\
\hline \multirow[t]{2}{*}{8} & $0-13$ & 9 & 42 & 5 & 0,92 & 34 & 8 & 5,1 \\
\hline & $13-33$ & 8 & 50 & 5 & 0,34 & 24 & 14 & 2,6 \\
\hline \multirow[t]{2}{*}{9} & $0-28$ & 5 & 68 & 4 & 0,94 & 17 & 8 & 3,4 \\
\hline & $28-46$ & 5 & 74 & 5 & 0,82 & 21 & 5 & 5,4 \\
\hline \multirow[t]{2}{*}{10} & $0-15$ & 18 & 62 & 8 & 0,28 & 34 & 13 & 4,2 \\
\hline & $15-30$ & 12 & 68 & 8 & 0,27 & 25 & 9 & 1,7 \\
\hline \multirow[t]{2}{*}{11} & $0-15$ & 38 & 52 & 8 & 0,35 & 27 & 18 & 1,7 \\
\hline & $15-47$ & 20 & 80 & 9 & 0,54 & 29 & 14 & 3,1 \\
\hline
\end{tabular}

According to the content of microelements, the investigated soils in the north-western and southern parts of the Absheron peninsula can be grouped according to the degree of concentration. Zinc, copper and cadmium are the most concentrated in comparison with others. Depending on the location of key areas of man-made emissions, the content of heavy metals varies. So in the Sumgait massif, 150 $\mathrm{m}$ northwest of the superphosphate plant, the concentration of zinc is 1.5 times, copper is 3 - 3.5 times higher than the allowable concentration in clarks. Retaining to the north by $500 \mathrm{~m}$, their concentration decreases by an order of magnitude. Compounding, 
zinc 88 and cadmium $0.36(\mathrm{mg} / \mathrm{kg})$. In the north-west direction, the concentration of copper is markedly low; at the top of the soil is $5-9 \mathrm{mg} / \mathrm{kg}$. To the south of the source of pollution, the values of the elements increase, amounting to: zinc - 84, cadmium - 0.94 and copper - 67 (mg/kg).

Probably, the excess of the concentration of elements in the soils located to the south in comparison with the northern part, despite the longer distance, is due to the prevalence of winds of the northern direction on the peninsula. Many of the elements have a tendency to wash soil from the surface and accumulate in the lower layers, and cadmium inherent properties accumulate in the top layer of soil and poorly resist degradation in natural environment, which greatly complicates their purification. The next According to the content of microelements, the investigated soils in the northwestern and southern parts of the Absheron peninsula can be grouped according to the degree of concentration. Zinc, copper and cadmium are the most concentrated in comparison with others.

Depending on the location of key areas of man-made emissions, the content of heavy metals varies. So in the Sumgait massif, 150 $\mathrm{m}$ northwest of the superphosphate plant, the concentration of zinc is 1.5 times, copper is $3-3.5$ times higher than the allowable concentration in clarks. Retaining to the north by $500 \mathrm{~m}$, their concentration decreases by an order of magnitude. Compounding, zinc 88 and cadmium 0.36 ( $\mathrm{mg} / \mathrm{kg}$ ). In the north-west direction, the concentration of copper is markedly low, at the top of the soil is $5-9 \mathrm{mg} / \mathrm{kg}$. To the south of the source of pollution, the values of the elements increase, amounting to: zinc - 84, cadmium - 0.94 and copper - 67 (mg / kg). Probably, the excess of the concentration of elements in the soils located to the south in comparison with the northern part, despite the longer distance, is due to the prevalence of winds of the northern direction on the peninsula.

Many of the elements have a tendency to wash soil from the surface and accumulate in the lower layers, and cadmium inherent properties accumulate in the top layer of soil and poorly resist degradation in natural environment, which greatly complicates their purification. The next group includes lead, the indices of which are close to the Clark units. This element has fairly high values in sedimentary deposits, in some cases exceeding the geochemical background. Concentration of lead is close to clark units in the north-west, northeast and south directions ( $9 \mathrm{mg} / \mathrm{kg}$ ), almost 2-3 times higher than the southern direction. Such an increased content of lead is probably due to the influence of the elevation of highly mineralized chloride waters to the surface. The third group of metals - chromium, copper ( $\mathrm{Cu}$ - only in certain directions), cobalt and nickel have a lower content of elements in soils-in tens, even hundreds of times, less than the permissible standards in all directions of the superphosphate plant.

The lower content of these elements in soils is caused by their low mobility in the alkaline medium. Zinc exceeds the permissible concentration $100 \mathrm{~m}$ south of the plant by almost 2 times, amounting to $170 \mathrm{mg} / \mathrm{kg}$. Concentration of lead has approximate values for clarks, making $9 \mathrm{mg} / \mathrm{kg}$ to the south (100 m from the enterprise) and exceeding them in 1,5-2 times, closer to the highway (50 m from the road), making 16-21 mg / kg Concentration Copper in this part of the object exceeds the Clark units in 4 times ( $85 \mathrm{mg} / \mathrm{kg}$ ). The absorption of copper and zinc in the dissolved state differs from the damage of the applied elements in the form of a powder. Since this chemical element is absorbed 3 times more in the dissolved state than in the solid state. Mercury enters the lithosphere and the atmosphere in the form of waste. Mercury sludge belongs to the 1st category of hazardous substances.

When mercury sludge is in open space for a long time, it is a serious threat, as waste that occupies a huge area spreads through the open airspace and penetrates into water sources and the atmosphere of residential areas. Considering that mercury is an active substance and can quickly evaporate the waste can be considered a source of danger, which accumulates mainly on the surface of the soil. In addition to determining the presence of heavy metals in the soil around the perimeter of industrial plants, several kinds of fertilizers have been used in our studies for beet and coniferous trees. Of these, vermikompostnoe as an organic - mineral, manure of cattle - as an organic, and as a mineral-ammonium nitrate and potassium sulfate. The results of the analyzes showed that due to the use of fertilizers and vermicomposts, heavy metals were deactivated from the soil, which is the result of the primary stage.

Microorganisms present in the soil composition, influence the dissolution of heavy metals and their direct appropriation by plants. For example, as a strain called Pseudomonas Maltophili can turn a toxic $\mathrm{Cr}+6$ into a harmless form of $\mathrm{Cr}+3$, unevenly spreading in its various organs and tissues. Zn (zinc) mainly accumulates in the aerial part and especially in the old leaves. Heavy metals accumulate in the reproductive organs of plants less often than in vegetative organs. Absorption, transport, metabolism, distribution in tissues and organs of heavy metals, is related both to the species and to the variety of plants grown, Which are also affected by environmental and anthropogenic factors. Studies have shown that in the lower part of contaminated light gray-brown soils, depending on the type of contaminants, some changes in the color of the morphogenetic layers in gray-brown occur.

These kinds of pollution cause serious negative damage not only to the morphology of the soil, but also to the biocenosis as a whole. The absorption of heavy metals and atmospheric contaminants of plants can be considered as a complex chemical biological and physical process. In recent years, scientists strongly suggest planting trees and other plant species, where plants are regarded as a factor that purifies the air of the atmosphere. In a number of studies it was proved that the vegetation cover is an important factor contributing to the protection of the environment from contaminants. It should be noted that as a result of research, ecologists in recent years have identified such specific species of plant groups and endemic flora that adapt to soil contaminated with metals such as zinc, copper and nickel.

Since adapting to the environment, plants are getting used to being resistant to soils contaminated with heavy metals. Metals are usually stored in plant leaves. But when the content of metal in the 
soil exceeds the permissible norm, the plants are able to synthesize them. In particular, from the degree of contamination, the number of bacteria and microbacteria in the soil changes drastically. The amount of saprophytes of fungi of actinomycetes of Azotobacteria is considerably reduced. Oxidation-reduction reaction reduces the number of oxidizing bacteria and microbacteria. The presence of microorganisms in the soil, compared to heavy metals polluted with heavy metals, has an incomparable increase in the number of microorganisms in the variant with beet plantings, with the use of mineral and organomineral fertilizers up to 4400. Moreover, under coniferous plantations their number was 4200 , and in variants without fertilizers Decreasing to 3,800 (beet) and 3600 (pine), while in areas contaminated with heavy metals their presence is practically not fixed.

\section{Conclusion}

It was established that in the soil cover of the Sumgait massif, the concentration of zinc around the perimeter of industrial enterprises varies with distance from the source of pollution, amounting to (Zn -48-84 mg / kg, Pb-5-9 mg / kg, Cd-0.82- 0.94 $\mathrm{mg} / \mathrm{kg}$.

It was revealed that the productivity of the dominant plant communities and the largest reserves of phyto mass of the Sumgait massif falls on the eastern part of the superphosphate plant (15.7 - 17.2 c / ha).

\section{References}

1. Akhundov AB (1999) Study of basic microelements in the soils of the Absheron Peninsula. Protection of life. Mathier 2nd Int. Scientific Conf Sumgait p. 39-40

2. Babayev A Kh (2007) Monitoring of soil quality and environmental monitoring. Baku p. 255.

3. (2007) Biodiversity and climate diversity. SVD, UNEP.

4. Gasanov VG (1987) Soil map of Absheron peninsula 1: 50000 scale, IPA AN SSSR Foundation, Baku.

5. Kulieva EN (2006) Ecological assessment of technologically-disturbed soils of Absheron. Author kand diss. Baku, p. 16s

6. Smirnov Loginov VP (1927) Soils of Absheron peninsula. Baku.

7. Mamedov GSh, Khalilov My (2005) Ecology and environmental protection. Baku, p. 880.

8. Flint VE (2002) Conservation and restoration of biodiversity. Moscow: Izd. Scientific and educational methodical center p. 282.

9. Shirinov NSh (1958) Geomorphological zoning of Absheron The peninsula. Baku, Academy of Sciences of Azerbaijan Republic, series geol Nauk p. 6.

10. Shikhlinsky EM (1968) The climate of Azerbaijan, Baku p. 341.

\begin{tabular}{ll}
\hline $\begin{array}{l}\text { BIOMEDICAL } \\
\text { RESEARCHES }\end{array}$ & $\begin{array}{l}\text { Assets of Publishing with us } \\
\text { - Global archiving of articles }\end{array}$ \\
\hline
\end{tabular}

